\title{
Double burden of malnutrition among female college students of Paschim Medinipur District, India
}

\author{
Monalisha Manna ${ }^{1}$, Sakhi Samanta ${ }^{2}$, Nirmalya Kumar Sinha ${ }^{3, *}$, Smarajit Maiti $^{4}$ \\ ${ }^{1,2}$ Student, ${ }^{3}$ Part Time Teacher (Government Approved), ${ }^{4}$ Associate Professor \& Head, ${ }^{1-3}$ Dept. of Nutrition, Raja Narendra Lal \\ Khan Women's College (Autonomous), Midnapore, West Bengal, ${ }^{4}$ Dept. of Biochemistry and Biotechnology, \\ Midnapore, West Bengal, India
}

*Corresponding Author:

Email: nksinhakgp@gmail.com

\begin{abstract}
Some previous report reveals that environmental and geographical factors have influence the regional health standard. Paschim Medinipur District in India is semi urban and rural based region adjoined to some Jangal Mahal Districts with laterite soil with lower crop fertility. The college students of Paschim Medinipur District and their health standard have not been systematically explored with reference to the state, country and further global standard. In the current study female students of a women's college in this region has been employed for this kind of analysis. It was noted that their health status is significantly undernourished and malnourished with comparison to the World Health Organization Global and Indian standard. Sociodemographic condition of the inhabitant, soil quality and the water standard may be a determining factor for the proper macronutrient metabolism. Synergistic action of micro- and macro-nutrient might be the factor which should be explored in future studies.
\end{abstract}

Keywords: College students, Obesity, Undernutrition.

\section{Introduction}

India has now experienced the double burden of malnutrition (underweight and overweight/obesity) like many other developing countries. ${ }^{1,2}$ Undernutrition and the micronutrient deficiencies are a days old public health problems in India, but till persists, while overweight/obesity are the emerging public health issues. ${ }^{3,4}$ Inappropriate combination of foods and inadequate intake of quality food is common in young people and their immature and their irrational attitude are one of the causes for malnutrition. ${ }^{5,6}$ The physical inactivity, junk food intake, spending more time in electronic media are the other causes of obesity among college students. ${ }^{5,7}$

Obesity is now regarded as global epidemic. The prevalence of obesity is rapidly increasing in the developed countries as well as developing countries during the few last decades ${ }^{8-10}$ Recent report of World Health Organization indicated that, obesity has about tripled globally since $1975 .{ }^{11}$ Obesity has a direct relationship with many chronic diseases including hypertension, coronary heart disease, type- 2 diabetes mellitus, osteoarthritis, dyslipidemia, cholethiasis and certain types of cancer in all most all human organs. ${ }^{12-15}$ obesity is also responsible factors for different gynaecological disorders including amenorrhoea, menstrual irregularities, polycystic ovarian disease and infertility etc. ${ }^{15}$ obesity has also negative role on the academic performance during the student life. ${ }^{16}$

On the other hand, underweight/undernutrition is usually an outcome of inadequate dietary intake and/or diseases. It hampers the immune system of the body that leads to longer, more severe and more frequent illness. ${ }^{17}$

The coexistence of undernutrition (underweight) and overnutrition (overweight/obesity) in the same population make the double burden for the society. In the developing countries, little work has been done on the obesity and mainly focus on the prevalence of undernutrition and particularly its causes and consequences..$^{17,18}$ In this scenario, this study was conducted to find out the prevalence of undernutrition and overweight/obesity among the female college students in a women's college situated in a semi-urban location.

\section{Materials and Methods Study Location and Human Participants}

The community based cross sectional study was conducted from September 2018 to November 2018. The present study was carried out among the female students aged between 18 and 20 years and inhabitants of Pachim Medinipur district or its neighbourhood areas.

\section{Ethical Consideration}

The study is approved by the Institutional Research Ethics Committee. The importance of the study was explained to potential participants and the students who gave written consent were included in the study. The anonymity of the participants is absolutely conserved.

\section{Inclusion Criteria}

Only the competent, consistent and psychologically healthy young adult female aged 18 to 20 years were included in this study. The participants who were suffering from significant health complication viz. 
diabetes, hypertension and chronic infectious diseases were not included in the study.

Anthropometric Measurement: All the anthropometric measurements were taken by the trained professionals using the standard techniques. ${ }^{19}$ height was measured to the nearest $0.1 \mathrm{~cm}$ with the participant standing in erect position on a flat platform with the head oriented in the Frankfort horizontal plane using Martin's anthropometer. Body weight was recorded digitally with a weighing scale (Doctor Beliram and Sons, New Delhi, India) to the nearest $0.1 \mathrm{~kg}$ with the participant standing motionless. Errors of measurements were computed within acceptable limits. ${ }^{20}$

The body mass index (BMI) of the individuals were computed using the standard equations: BMI $\left(\mathrm{kg} / \mathrm{m}^{2}\right)=$ Weight $(\mathrm{kg}) /$ height $^{2}\left(\mathrm{~m}^{2}\right)$. Nutritional status was evaluated using internationally accepted BMI guidelines. ${ }^{21}$ The following cut-off points were utilized: Grade III Thinness: BMI<16.0.

a) Grade II Thinness: BMI=16.0-16.99.

b) Grade I Thinness: BMI=17.0-18.49.

c) Normal: BMI=18.50-24.99.

d) Overweight: $\mathrm{BMI} \geq 25.0$.

To determine the condition of the population according the prevalence of low BMI $<18.5$ the WHO Classification of public health problem of low BMI based on BMI distribution in adult populations were followed (Table 1). ${ }^{21}$

The neck-circumference (NC) of the individuals was measured as length around the neck in a horizontal plane at the level of the most prominent portion of the thyroid cartilage (Adam's apple) with the head at erect and resting position. ${ }^{22-24}$

Table 1: Classification of public health problem of low BMI based on BMI distribution in adult populations ${ }^{21}$

\begin{tabular}{|l|c|}
\hline \multicolumn{1}{|c|}{ Classification } & $\begin{array}{c}\text { Percentage of population with } \\
\text { BMI<18.5 }\end{array}$ \\
\hline $\begin{array}{l}\text { Low prevalence (Warning sign, monitoring } \\
\text { required) }\end{array}$ & $5-9 \%$ \\
\hline Medium prevalence (Poor situation) & $10-19 \%$ \\
\hline High prevalence (Serious situation) & $20-39 \%$ \\
\hline Very high prevalence (Critical situation) & $\geq 40 \%$ \\
\hline
\end{tabular}

Table 2: Age and anthropometric parameters of the female college students aged 18-20 years

\begin{tabular}{|l|c|c|}
\hline Parameters & Mean \pm SD & 95\% CI \\
\hline Age $($ years $)$ & $19.20 \pm 0.75$ & $19.01-19.38$ \\
\hline NC $(\mathrm{cm})$ & $30.30 \pm 2.25$ & $29.75-30.86$ \\
\hline Weight $(\mathrm{kg})$ & $49.71 \pm 8.33$ & $47.66-51.76$ \\
\hline Height $(\mathrm{cm})$ & $154.45 \pm 5.28$ & $153.15-155.75$ \\
\hline BMI $\left(\mathrm{kg} / \mathrm{m}^{2}\right)$ & $20.87 \pm 3.56$ & $19.99-21.75$ \\
\hline
\end{tabular}

Table 3: Pearsons product moment correlation between age and different anthropometric parameters.

\begin{tabular}{|l|c|c|c|c|}
\hline Parameters & NC (cm) & Weight $(\mathbf{k g})$ & Height $(\mathbf{c m})$ & BMI $\left(\mathbf{k g} / \mathbf{m}^{2}\right)$ \\
\hline Age $($ years $)$ & 0.086 & 0.009 & -0.030 & 0.024 \\
\hline NC $(\mathrm{cm})$ & & $0.828 * * *$ & 0.066 & $0.796 * * *$ \\
\hline Weight $(\mathrm{kg})$ & & & 0.170 & $0.918 * * *$ \\
\hline Height $(\mathrm{cm})$ & \multicolumn{5}{|c|}{ Significant at $* * * \mathrm{P}<0.001$} \\
\hline \multicolumn{5}{|l|}{} \\
\hline
\end{tabular}

\section{Statistical Analysis}

The statistical analyses were computed by using the Statistical Package for Social Sciences (SPSS) for Windows statistical software package (SPSS Inc., Chicago, IL, USA, 2001). Normally distributed data were tested by Kolmogorov-Smirnov test. One-way ANOVA analysis was undertaken to test for age differences in mean height, weight, BMI and NC.
Product moment correlation coefficient (r) between intra-parameters of anthropometric measurements was also calculated. Linear regression analysis was done to assess the best anthropometric predictive of BMI and the coefficient of determination $\left(\mathrm{R}^{2}\right)$ and standard error of estimate (SEE) were calculated for NC. $\mathrm{P}$ value $<0.05$ is considered statistically significant. 
Table 4: Comparative prevalence of underweight and overweight/obese of women's of different districts of West Bengal with the present study ${ }^{27}$

\begin{tabular}{|l|c|c|}
\hline Districts & Underweight & Overweight/obese \\
\hline Bankura & 33.3 & 9.4 \\
\hline Barddhaman & 24.0 & 17.0 \\
\hline Birbhum & 30.3 & 10.3 \\
\hline Dakshin Dinajpur & 24.9 & 12.1 \\
\hline Darjiling & 15.4 & 23.6 \\
\hline Haora & 16.5 & 25.9 \\
\hline Huglii & 18.3 & 29.9 \\
\hline Jalpaiguri & 26.1 & 14.8 \\
\hline Koch Bihar & 24.8 & 9.7 \\
\hline Kolkata & 7.3 & 40.6 \\
\hline Maldah & 23.9 & 12.0 \\
\hline Murshidabad & 21.1 & 14.8 \\
\hline Nadia & 11.9 & 24.9 \\
\hline North24 Parganas & 11.5 & 28.9 \\
\hline Paschim Medinipur & 29.9 & 15.9 \\
\hline Purba Medinipur & 19.4 & 20.9 \\
\hline Puruliya & 47.5 & 4.7 \\
\hline South 24 Parganas & 18.8 & 22.6 \\
\hline Uttar Dinajpur & 25.7 & 11.1 \\
\hline $\begin{array}{l}\text { Paschim Medinipur } \\
\text { (Present Study) }\end{array}$ & $\mathbf{2 4 . 2}$ & $\mathbf{1 5 . 2}$ \\
\hline
\end{tabular}

Table 5: Comparative prevalence of underweight and overweight/obese of women's of different states/union territory of India with the present study ${ }^{28}$

\begin{tabular}{|c|c|c|c|c|}
\hline Eco-Zones of India & State/Union Erritory & $\begin{array}{c}\text { Mean } \\
\text { BMI }\end{array}$ & $\begin{array}{c}\text { Under } \\
\text { Weight }\end{array}$ & Overweight/Obese \\
\hline & India & 21.9 & 22.9 & 20.7 \\
\hline \multirow[t]{8}{*}{ North } & Chandigarh & 24.3 & 13.3 & 41.4 \\
\hline & Delhi & 23.5 & 14.8 & 33.5 \\
\hline & Haryana & 22.3 & 15.8 & 21.0 \\
\hline & Himachal Pradesh & 22.8 & 16.2 & 28.7 \\
\hline & Jammu \& Kashmir & 23.2 & 12.1 & 29.1 \\
\hline & Punjab & 23.5 & 11.7 & 31.3 \\
\hline & Rajasthan & 21.1 & 27.0 & 14.1 \\
\hline & Uttarakhand & 22.1 & 18.4 & 20.5 \\
\hline \multirow[t]{3}{*}{ Central } & Chhattisgarh & 20.9 & 26.7 & 11.9 \\
\hline & Madhya Pradesh & 21.0 & 28.4 & 13.6 \\
\hline & Uttar Pradesh & 21.4 & 25.3 & 16.5 \\
\hline \multirow[t]{4}{*}{ East } & Bihar & 20.6 & 30.5 & 11.7 \\
\hline & Jharkhand & 20.5 & 31.6 & 10.3 \\
\hline & Odisha & 21.3 & 26.5 & 16.5 \\
\hline & West Bengal & 21.8 & 21.3 & 19.9 \\
\hline \multirow[t]{8}{*}{ Northeast } & Arunachal Pradesh & 22.5 & 8.5 & 18.8 \\
\hline & Assam & 21.0 & 25.7 & 13.2 \\
\hline & Manipur & 23.0 & 8.8 & 26.0 \\
\hline & Meghalaya & 21.7 & 12.1 & 12.2 \\
\hline & Mizoram & 22.6 & 8.4 & 21.1 \\
\hline & Nagaland & 21.9 & 12.3 & 16.2 \\
\hline & Sikkim & 23.3 & 6.4 & 26.7 \\
\hline & Tripura & 21.7 & 19.0 & 16.0 \\
\hline \multirow[t]{3}{*}{ West } & Dadra \& Nagar Haveli & 21.4 & 28.7 & 19.2 \\
\hline & Daman \& Diu & 23.3 & 12.9 & 31.7 \\
\hline & Goa & 23.5 & 14.7 & 33.5 \\
\hline
\end{tabular}




\begin{tabular}{|l|l|c|c|c|}
\hline & Gujarat & 22.0 & 27.2 & 23.8 \\
\cline { 2 - 5 } & Maharashtra & 22.1 & 23.5 & 23.4 \\
\hline \multirow{5}{*}{ South } & Andaman \& Nicobar Islands & 23.3 & 13.1 & 31.8 \\
\cline { 2 - 5 } & Andhra Pradesh & 23.3 & 17.6 & 33.2 \\
\cline { 2 - 5 } & Karnataka & 22.3 & 20.8 & 23.3 \\
\cline { 2 - 5 } & Kerala & 23.5 & 9.7 & 32.4 \\
\cline { 2 - 5 } & Lakshadweep & 24.2 & 13.5 & 40.6 \\
\cline { 2 - 5 } & Puducherry & 23.9 & 11.3 & 36.7 \\
\cline { 2 - 5 } & Tamil Nadu & 23.2 & 14.6 & 30.9 \\
\cline { 2 - 5 } & Telangana & 22.6 & 22.9 & 28.7 \\
\hline \multirow{4}{*}{ East } & $\begin{array}{l}\text { West Bengal } \\
\text { Study) }\end{array}$ & $\mathbf{2 0 . 9}$ & $\mathbf{2 4 . 2}$ & $\mathbf{1 5 . 2}$ \\
\hline
\end{tabular}

Table 6: Prevalence of underweight among adults $(B M I<18)$ and overweight $(B M I \geq 25)$ crude Estimates by WHO region ${ }^{29,30}$

\begin{tabular}{|l|l|l|}
\hline WHO region & $\begin{array}{l}\text { Underweight } \\
\text { (crude stimate) } \\
(\mathbf{\%})\end{array}$ & $\begin{array}{l}\text { Overweight } \\
\text { (crude estimate) }(\boldsymbol{\%})\end{array}$ \\
\hline Africa & $9.9[8.2-11.9]$ & $34.8[32.2-37.5]$ \\
\hline Americas & $2.2[1.7-2.8]$ & $62.1[59.3-64.9]$ \\
\hline South-East Asia & $20.8[17.0-24.8]$ & $23.7[20.7-27.0]$ \\
\hline Europe & $1.9[1.5-2.4]$ & $58.8[56.2-61.4]$ \\
\hline Eastern Mediterranean & $7.6[5.7-9.7]$ & $49.8[46.9-52.8]$ \\
\hline Western Pacific & $7.2[5.5-9.4]$ & $31.1[27.3-35.1]$ \\
\hline (WHO) Global & $9.4[8.1-10.7]$ & $39.7[37.8-41.6]$ \\
\hline $\begin{array}{l}\text { South-East Asia } \\
\text { (Present study) }\end{array}$ & $\mathbf{2 4 . 2 4}[\mathbf{1 3 . 6}-$ & $\mathbf{1 5 . 1 5}[\mathbf{6 . 3 - 2 4 . 0}]$ \\
\hline
\end{tabular}
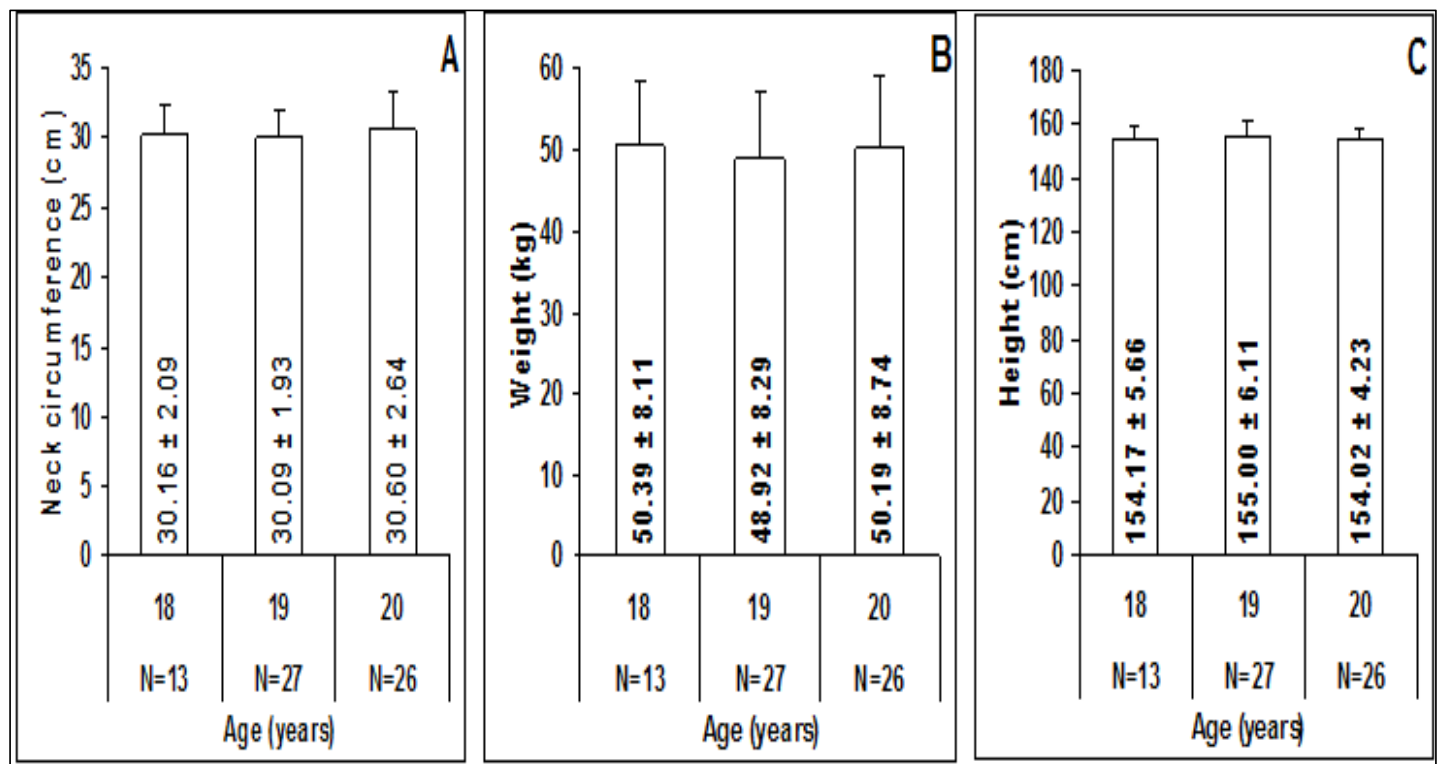

Fig. 1: (A-C): Impact of age on neck circumference, weight and height of the female college students. 


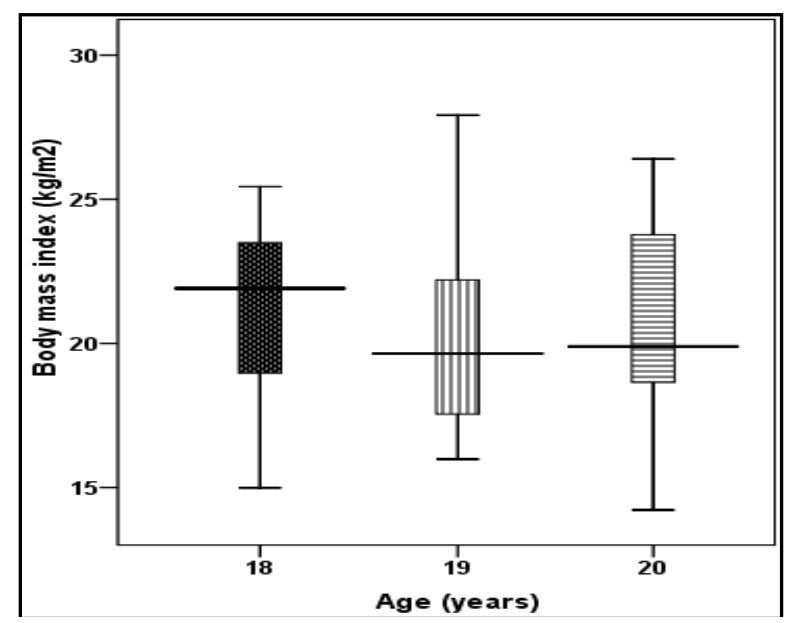

Fig. 2: Box plot of Body mass index $\left(\mathrm{kg} / \mathrm{m}^{2}\right)$ among the female college students according to age.

\section{Results}

The study group was consisted of sixty six female undergraduate students. The mean and standard deviation of the age of the students were $19.20 \pm 0.75$ (years 19.01-19.38 years) with a range of 18 to 20 years (Table 2). The students were segregated into three groups, according to their age viz. 18, 19 and 20 years. The frequency of these age-groups was 13, 27 and 26 respectively. The mean BMI and $\mathrm{NC}$ of the students were $20.87 \pm 3.56 \mathrm{~kg} / \mathrm{m}^{2} \quad\left[19.99-21.75 \mathrm{~kg} / \mathrm{m}^{2}\right]$ and $30.30 \pm 2.25 \mathrm{~cm}[29.75-30.86 \mathrm{~cm}]$ respectively (Table 2).

Fig. 1 shows the mean of $\mathrm{NC}$, height, weight according to age. The study showed that $\mathrm{NC}$ was highest among the students of 20 years though no significant age difference was observed $(\mathrm{F}=0.361$; $\mathrm{P}>0.05$ ).

Fig. 2 shows the box plot of BMI according to age. The mean BMI of the students of 18,19 and 20 years were $21.19 \pm 3.10 \mathrm{~kg} / \mathrm{m}^{2}, \quad 20.41 \pm 3.58 \mathrm{~kg} / \mathrm{m}^{2}$ and $21.19 \pm 3.82 \mathrm{~kg} / \mathrm{m}^{2}$ with $\mathrm{F}=0.371(\mathrm{P}>0.05)$.

While studying the intra-relationship of the anthropometric parameters, it was noted that $\mathrm{NC}$ positively associated with weight and BMI (Table 3 ).

The linear regression analysis indicated that the NC of the students was considered to be a significantly $(p<0.01)$ better predictor variable of BMI (Fig. 3 ).

The prevalence underweight and overweight among the students was $24.24 \%$ and $15.15 \%$ respectively (Fig. 4). The prevalence of Grade III Thinness, Grade II Thinness, Grade I Thinness among the students were $4.54 \%, 9.09 \%$ and $10.61 \%$ respectively (Data not shown). Figure 4 also shows that the highest prevalence of underweight was noted among the female students of 19 years $(29.63 \%)$ while highest prevalence of overweight was observed among the students of 20 years $(19.23 \%)$.

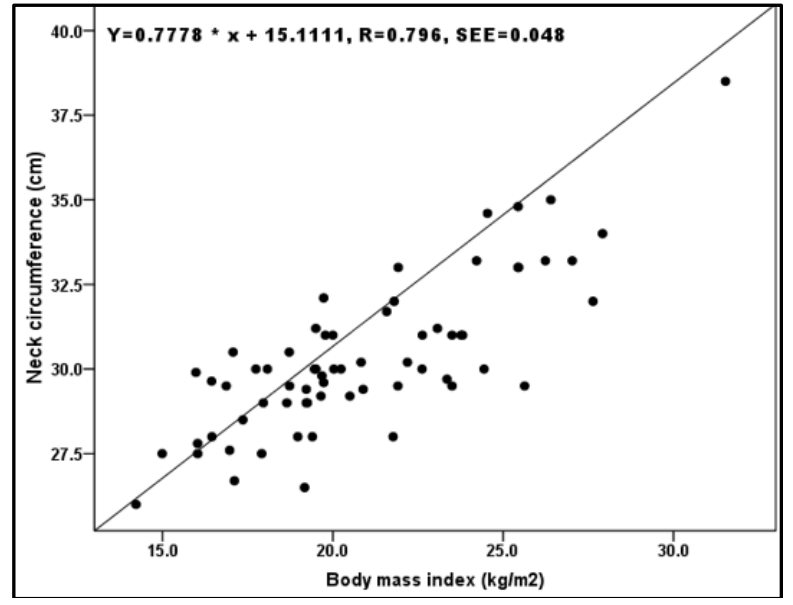

Fig. 3: Linear regression analysis between NC and BMI. 


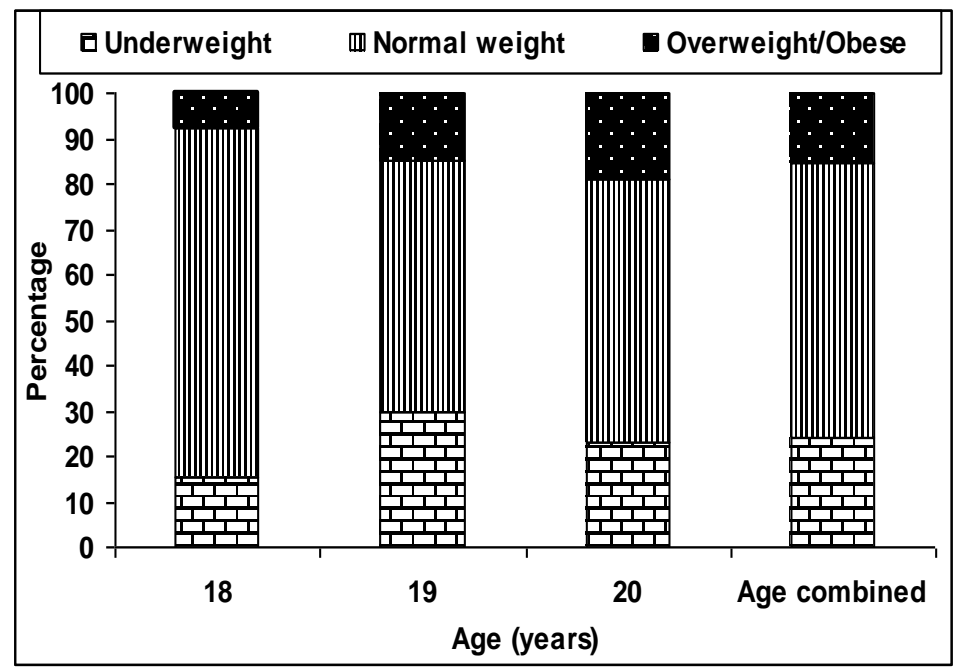

Fig 4: Impact of age on the prevalence of underweight and overweight/obese of the female college students

\section{Discussion}

The recent report of World Health Organization (WHO, 2011) stated that the undernutrition and infectious diseases continue to threat serious health challenges in low-income countries. But overweight/obesity assumes important and major risk factors for cardiovascular diseases in the same settings. ${ }^{25}$ it was well known that the overweight/obesity has been regarded as an alien phenomenon in many developing countries. ${ }^{26}$ It has been raised dramatically in last few decades. Thus, overweight/obesity has become one of the major public health issues while undernutrition still raises a typical challenge in the developing countries. ${ }^{17}$

The double burden of malnutrition also found in this study population, and the underweight $(24.24 \%)$ were more prevalent than the overweight $(15.15 \%)$ among the female students of Pschim, Medinipur District. This high prevalence of undernutrition among these students put the population is in serious situation as indicated by the WHO classification of public health problem of low BMI. ${ }^{21}$ The recent study of National Family and Heath Survey-4 indicated that the prevalence of underweight and overweight among the adult female of Pschim, Medinipur District was 29.9\% and $15.9 \%$ respectively. ${ }^{27}$ In the present study, the prevalence of the overweight was similar to the previous study. But the prevalence of the underweight is higher in the previous study. While comparing this finding with the state level report documented in National Family and Heath Survey-4, it was noted that the prevalence of underweight was higher in the present study $(24.24 \%)$ than the previous report $(21.3 \%)$ and prevalence of overweight were lower than the previous report $(19.9 \%) .{ }^{28}$ But when comparing the data of all over India it was noted that the prevalence of underweight of the female students were higher than the adult women of all over India (22.9) and are less likely to be overweight in comparison to that of the adult women of all over India (20.7\%). ${ }^{28}$ The recent report of WHO. ${ }^{29,30}$ indicated that the female participants of Paschim, Medinipur, Districts are very much prone to underweight than the female of this earth. As the global prevalence of underweight and overweight among the females were $9.4 \%$ and $39.7 \%$.

\section{Conclusion}

The socio-economic and geographical parameters could have been strong determinant in the assessment of health standard. In the present study the evaluation on the severity of undernutrition in the Midnapore region demands more focus on the socio-geographical parameters in this region. Some natural adverse situation like water quality with mineral and micronutrient availability may be drastically limited. And this may be a serious factor which has been overlooked and only the macronutrient factors are considered. But the normal metabolism and growth could have been only possible in the synergistic implications of different nutritional factors. This should be elaborately explored in future.

\section{References}

1. Ke-You G, Da-Wei F. The magnitude and trends of under and over-nutrition in Asian countries. Biomed Environ Sci. 2001;14:53-60.

2. Swaya AL, Dallal G, Solymos G, de Sousa MH, Ventura ML, Roberts SB, Sigulem DM. Obesity and malnutrition in a Shantytown population in the city of Sao Paulo. Brazil. Obes Res. 1995;2 :107-15

3. Bhardwaj S, Misra A, Khurana L, Gulati S, Shah P, Vikram NK. Childhood obesity in Asian Indians: A burgeoning cause of insulin resistance, diabetes and sub clinical inflammation. Asia Pac J Clin Nutr. 2008; 17(1):172-75

4. Singal N, Misra A, Rastogi K Shah P, Vikram NK. Secular trends in obesity, regional adiposity and metabolic parameters among Asian Indian adolescents in North India: A comparative analysis of data 5 years apart - 2003, 2008. Ann Nutr Metab. 2010;56(3):17681. 
5. Money V, Jesha MM, Haveri SP, Sebastian NM, Nath AS. Malnutrition among medical students in north Kerala. Eur J Pharmaceutical Med Res. 016;3(5):32529.

6. Brint A, Rhee Y, Zhong L. Differences in dietary patterns among college students according to Body Mass Index. J Am College Health, 2008;56:629-34.

7. Akhter M, Biswas SN, Ansari MH. Nutritional status among students of a private medical college of Bangladesh. KYAMCJ. 2015;6(1):579-82.

8. Popkin BM. The nutrition transition: An overview of world patterns of change. Nutr Rev. 2004;62:Sl 40-S1 43.

9. Prentice AM. The emerging epidemic of obesity in developing countries. Int J Epidemiol. 2006;35:93-9.

10. Madanat HN, Troutman KP, Al-Madi B. The nutrition transition in Jordan: the political, economic and food consumption contexts. Promot Educ. 2008;15(1):6-10.

11. https://www.who.int/news-room/factsheets/detail/obesity-and-overweight.

12. Manson JE, Skerrette PJ, Greenland P, Vanltallie TB. The escalating pandemics of obesity and sedentary lifestyle a call to action for clinitians. Arch Intern Med. 2004;164:249-58.

13. Visscher TLS, Seidell JC. The public health impact of obesity. Annu Rev Public Health. 2001;22:355-75.

14. World Health Organization. Obesity: Preventing and managing the global epidemic. WHO Tech Report 2000;894.

15. Ogunbode AM, Fatiregun AA, Ogunbode OO. Health risks of obesity. Ann Ib Postgrad Med. 2009;7(2):2225.

16. Visscher T, Seidell J.The public health impact of obesity. Аnпи Rev Public. 2001;22:355-75.

17. Oladoyinbo CA, Ekerette NN. Double burden of malnutrition among undergraduates in Ogun State Nigeria. Int J Public Health Sci. 2015;4(4):315-19.

18. Akpa MR, Mato CN, Obesity in Nigeria: current trends and management. Nigeria Medical Practitioner. 2008;54:11-15.
19. Lohman TG, Roche AF, Martorell R. Anthropometric standardization reference manual. Chicago: Human Kinetics Books. 1998.

20. Ulijaszek SJ, Kerr DA. Anthropometric measurement error and the assessment of nutritional status. $\mathrm{Br} \mathrm{J}$ Nutr. 1999;82:165-77.

21. World Health Organization. Physical Status: The Use and Interpretation of Anthropometry. Technical Report Series 854. Geneva: World Health Organization. 1995.

22. Fink B. 2012. Neck circumference: its usage in medicine and biology. - In VR Preedy (eds). Handbook of Anthropology: Physical Measures of Human Form in Health and Disease. New York: Springer Science. 2012.

23. Ben-Noun L, Sohar E, Laor A. Neck circumference as a simple screening measure for identifying overweight and obese patients. Obes Res. 2001;9:470-77.

24. Hall JG, Allanson JE, Gripp KW, Slavotinek AM. Handbook of Physical Measurements. New York: Oxford University Press. 2007.

25. World Health Organization, Obesity and overweight. Geneva: Switzerland: World Health Organization. 2011. Available from: http://www.who.int/mediacentre/factsheets/fs311/en/pr int.html.

26. Wang Y, Chen HJ, Shaikh S, Mathur P. Is obesity becoming a public health problem in India? Examine the shift from under- to over-nutrition problems over time. Obes Rev. 2009;10:456-74.

27. National Family Health Survey, India. KEY FINDINGS FROM NFHS-4. http://rchiips.org/NFHS/WB.html.

28. International Institute for Population Sciences (IIPS) and ICF. National Family Health Survey (NFHS-4), 2015-16: India. Mumbai: IIPS. 2017.

29. Un:http://apps.who.int/gho/data/view.main.NCDBMIL T18CREGv?lang=en.

30. Over: http://apps.who.int/gho/data/view.main.BMI25CREGv ?lang=en. 